\title{
SOCIETAS DELIQUERE POTEST E OS DELITOS AMBIENTAIS À LUZ DAS JURISPRUDÊNCIAS DO SUPREMO TRIBUNAL FEDERAL E DO SUPERIOR TRIBUNAL DE JUSTIÇA
}

JARDEL de Freitas SOARES

Doutor em Ciências Jurídicas e Sociais (UMSA), professor de Direito Ambiental e Direito Processual Penal, Universidade Federal de Campina Grande (UFCG). Lattes: http://lattes.cnpq.br/7938280572677319. E-mail: jardel.soares@uol. com.br

\section{Resumo}

Os debates penais e as jurisprudências contemporâneas dos tribunais superiores brasileiros são polêmicos em alguns ideais e marcos teóricos sobre o tema societas deliquere potest. As principais organizaçôes capitalistas, as pessoas jurídica, são as que mais agridem o meio ambiente, esse bem jurídico tão valioso e insubstituível, e que por isso merece destaque no que diz respeito à responsabilidade criminal. $\mathrm{O}$ objetivo é, portanto, promover uma abordagem inovadora e uma crítica paralela acerca da responsabilidade penal das pessoas jurídicas por danos ambientais. A metodologia utilizada na pesquisa consiste no método investigativo e descritivo, pois visa proporcionar uma maior familiaridade com o problema e torná-lo explícito, além de construir novas hipóteses. A técnica metodológica realiza-se em uma ampla pesquisa nas doutrinas, nos meios eletrônicos oficiais e principalmente nas jurisprudências dos Tribunais Superiores nacionais. Desse modo, observa-se que a proteção ao meio ambiente é ligada ao direito à vida, não somente as vidas dos seres humanos, mas de todo o planeta, e a Ciência Penal não pode ficar inerte diante do avanço da macrocriminalidade ambiental provocada pelas entidades corporativas.

\section{Palavras-chave}

Jurisprudências; Pessoa Jurídica; Responsabilidade Criminal; Meio Ambiente.

\section{Resumen}

Los debates penales y las jurisprudencias contemporáneas de los tribunales superiores brasileños son polémicos en algunos ideales y marcos teóricos sobre el tema societas deliquere potest. Las principales organizaciones capitalistas, las personas jurídicas, son los más ofensivos para el medio ambiente, que es un bien jurídico tan valioso e insustituible, 
y por lo tanto merece importancia con respecto a la responsabilidad criminal. El objetivo es, pues, promover un enfoque innovador y una crítica paralela sobre la responsabilidad penal de las personas jurídicas por los daños ambientales. La metodología utilizada en la investigación es el método investigativo y descriptivo, pues pretende proporcionar una mayor familiaridad con el problema y hacerlo explícito, además de construir nuevas hipótesis. La técnica metodológica se realiza en una amplia investigación en las doctrinas, en los medios electrónicos oficiales y principalmente en las jurisprudencias de los Tribunales Superiores nacionales. Ese modo, se observa que la protección del medio ambiente es relacionada con el derecho a la vida, no sólo las vidas de los seres humanos, sino de todo el planeta, y la Ciencia Penal no puede quedarse inerte ante el avance de la macrocriminalidad ambiental causado por las entidades corporativas.

\section{Palabras clave}

Jurisprudencias; Personas Jurídicas; Responsabilidad Criminal; Medio ambiente.

\section{Introdução}

A atual ordem político-econômica mundial caracterizada pela globalização faz surgir a macrocriminalidade. Agora os bens tutelados atingidos são macrossociais, como o meio ambiente, cujos resultados danosos atingem a todos indistintamente. As medidas de responsabilização cível e administrativa já não são mais suficientes para coibir a degradação ambiental, surge entáo à responsabilização criminal, como meio ultima ratio para amenizar esse avanço prejudicial.

Justifica-se nos seguintes aspectos a pesquisa acadêmica:

No que tange a importância técnico-científica, decorre da impossibilidade de sobrevivência do ser humano sem que sejam utilizados os recursos naturais.

Social e economicamente, observa-se o fato de ser o meio ambiente indispensável à sobrevivência humana, como também, uma forma de combater a pobreza por meio de uma política ecológica sustentável.

No que se refere às motivaçóes jurídicas e ambientais, está o estímulo a uma conscientização de tutela penal e ambiental, no intuito de assegurar que as geraçóes vindouras tenham condiçôes de desfrutar de um meio ambiente equilibrado.

Diante de tais argumentos, surge então a seguinte problemática: qual a relação jurídico-penal entre os crimes ecológicos cometidos pelas empresas e a degradação ambiental constatada no Brasil à luz dos julgados dos tribunais superiores brasileiros?

O objetivo geral do trabalho é analisar as teorias e as aplicaçóes jurisprudenciais da responsabilização das pessoas jurídicas face aos crimes ecológicos. No que se refere 
aos objetivos específicos são os seguintes: provar que a responsabilidade penal das pessoas jurídicas por danos ambientais é seguramente compatível com a teoria do crime, da culpabilidade e das funções da sanção penal. Traçar um paralelo sobre as conseqüências práticas da degradação ambiental advindas após o surgimento da globalização e a parcela de contribuição das pessoas jurídicas. Estabelecer as vantagens, desvantagens e um estudo de Direito Comparado sobre a responsabilização das pessoas jurídicas com relação à tutela ambiental e penal.

A metodologia empregada consiste no método investigativo e descritivo, ou seja, utiliza-se uma profunda pesquisa nas doutrinas e julgados brasileiros e estrangeiros com a finalidade de um maior aprofundamento da evolução histórica, da conceituação teórica e da aplicação prática dos sistemas jurídicos. Na busca de respostas para as inquietaçóes levantadas usa-se de métodos interpretativos próprios das Ciências Criminais e de Ciências afins. Quanto aos métodos de procedimento, vislumbram-se o histórico, o comparativo e o exegético-jurídico de maneira a confirmar ou refutar as hipóteses levantadas a partir da problemática do estudo. A técnica é a documentação indireta, através da pesquisa bibliográfica em livros, periódicos, acervos de arquivos públicos e particulares e especialmente nas jurisprudências dos tribunais superiores pátrios, além de artigos jurídicos e endereços eletrônicos oficiais.

Pela exposição inicial, demonstra-se a enorme necessidade em pesquisar sobre a responsabilização da pessoa jurídica por delitos ambientais nas relações de desenvolvimento econômico. Em verdade, é difícil a tarefa de estudar essa questão, porém, não restam dúvidas sobre a importância da temática e sua aplicação cotidiana.

\section{A Evolução Histórica e o Direito Comparado da Responsabilidade Penal da Pessoa Jurídica}

Durante a evolução da sociedade houve períodos em que se aceitava a responsabilidade do ente coletivo e em outros não.

Quando a sociedade passou a organizar-se em gens (famílias) algumas regras de condutas foram impostas, como por exemplo, caso algumas normas de conduta fossem desobedecidas por um dos seus membros toda a comunidade personificada passaria a ser punida, tal medida aconteceu no período Babilônico com a criação do Código de Hamurabi (século XXIII a. C.). Outra exemplificação é o Código de Manú (século XIII a. C.), implementado na Índia, onde a punição tornou-se uma marca de cunho religioso que poderia ser aplicada inclusive aos descendentes dos criminosos que ainda não nasceram. Tão logo, a responsabilidade penal familiar tornou-se as premissas para a atual penalização do ente coletivo.

No período do Direito Romano inicialmente devido a sua característica de praticidade náo se adotava o conceito de personalidade da pessoa jurídica. Com o advento 
do império surge a diferenciação, sem aprofundamento, de direitos e obrigações entre as corporaçôes (universitas, municipia e collegia) e as pessoas naturais que faziam parte dessas (singuli). No mais, o Direito Romano não se concebeu em regra a responsabilidade penal do ente coletivo (societas delinquere non potest). Com relação aos gregos a responsabilização criminal da pessoa coletiva com sançôes coletivas aplicadas aos grupos familiares ou clãs foi possível no século VII a. C.

Durante o início da idade média as entidades passaram a tornar-se economicamente e politicamente importantes no contexto da época. Com isso, os glosadores que desempenhavam a função de interpretar o Direito Romano, passaram a analisar que a corporação (universitas) era constituída de uma soma de direitos e obrigaçóes de seus membros, e, portanto, poderiam ser responsabilizadas tanto na esfera cível e penal quando a conduta dos seus representantes partisse de uma decisão conjunta e no interesse da atividade do ente coletivo. Nos meados do século XIII surgiram os pensamentos dos pós-glosadores, embora aceitando o entendimento de que a pessoa jurídica era uma ficção, admitiam a sua imputação criminal.

Foi no Direito Canônico que se construiu as bases da teoria da personalidade jurídica moderna. No período canonista, com forte influência do direito germânico, a igreja era considerada como a corporaçáo mais importante, pois a ideia que se impunha era a de que os direitos não pertenciam aos fiéis, mas sim ao poder divino, que era representado pelas corporaçóes eclesiásticas. As sanções as cidades, comunas, congregaçóes, conventos e entre outros poderiam ser de caráter material e espiritual. "Los canonistas, a su vez, trajeron a la luz la idea de persona ficta 'sive intelectuallis'." (LÓPEZ MESA; CESANO, 2000, p.24 - grifo no original).

Com a queda do autoritarismo Estatal e do corporativismo, as ideias iluministas e naturalistas, principalmente com o advento da Revolução Francesa, passaram a enfatizar mais a pessoa individual na ordem sócio-democrático do que mesmo a pessoa coletiva. Durante esse período o tema passou por um esquecimento, náo por causa de discussóes jurídicas, mas sim, por meramente questôes políticas e idealistas.

Contudo, diante do crescimento da importância dos entes jurídicos perante a conjuntura mundial houve nos últimos tempos encontros importantes para debater sobre o tema da imputabilidade penal das corporações. "Vários países, há tempos, avançaram rumo à responsabilidade criminal da pessoa jurídica, muito embora setores consideráveis de sua doutrina penalista fossem contrários a tal solução." (IENNACO, 2010, p.74).

Dessa forma, alguns blocos econômicos e naçôes ao longo anos adotaram conceitos favoráveis à aplicação da imputação criminal da empresa, assim:

$\mathrm{Na}$ Comunidade Européia foi previsto a responsabilidade penal da pessoa jurídica em particular nos artigos 85 e 86 do Tratado Constitutivo da Comunidade Européia (TCCE). De acordo com o Tratado as empresas e as associações comerciais ficam proibidas 
de restringir, impedir ou fraudar a concorrência instituída por lei, através de acordos, decisóes ou práticas concertadas, sejam dolosas ou culposas. As penalidades, que são exclusivas das pessoas jurídicas, já que a pessoa física que atuou em nome da empresa não é responsabilizada, variam de multa até a nulidade do ato, todavia, a sanção pode ser excluída se a conduta tiver como finalidade melhorar a produçáo ou distribuiçáo de produtos para o progresso técnico ou econômico do bloco europeu. Fato importante é que existe na resoluçáo de número 77 uma recomendaçáo aos países signatários para que seja levado em consideração o princípio da responsabilidade criminal do ente moral, público ou privado, para a proteção do meio ambiente.

No Mercosul, em seu âmbito foi criado o Protocolo de Defesa da Concorrência dos países que integram o Mercado Comum do Sul, assinado em 1996 na cidade de Fortaleza, Brasil, cujo objetivo é tornar livre e harmônico a circulação de riquezas entre os países do bloco mercosulino e combater a concorrência desleal. Nesse diapasão os artigos $2^{\circ}, 3^{\circ}$, $27^{\circ}, 28^{\circ} \mathrm{e} 29^{\circ}$ do mencionado Protocolo responsabiliza e penaliza as pessoas jurídicas, públicas ou privadas, que de alguma forma desobedeçam às normas pactuadas. Sem dúvida, o Protocolo que tutela a concorrência na economia do cone sul demonstra a preocupação, embora ainda muito tímida, em estabelecer as premissas de uma harmonizaçáo legal no Mercosul que responsabilize as corporaçôes. E no que se refere à tutela ambiental até o presente momento não existe previsão normativa a respeito.

$\mathrm{Na}$ Venezuela expressamente nos artigos $3^{\circ}, 4^{\circ}$ e $6^{\circ}$ da sua lei penal ambiental de número 4.358/92 a responsabilização criminal da pessoa jurídica por crime contra o meio ambiente, onde a pena pode variar de multa, proibição de contratar com o Estado, e até a medida de fechamento da entidade desde que o dano seja gravíssimo aos bens ecológicos.

Na Bolívia em 31 de março de 2010, promulgou-se a legislaçấo denominada de "lei da luta contra a corrupção, enriquecimento ilícito e investigação de fortunas”. Preleciona a lei de número 004 a responsabilidade penal da pessoa jurídica e a obrigaçáo de prevenir, investigar, processar e sancionar condutas de corrupção de seus prepostos, bem como, recuperar o erário publico afetado pelo ilícito.

No Chile existe a lei número 23.393/2009, que prevê a responsabilidade criminal do ente coletivo de maneira autônoma da responsabilidade do seu empregado que houver participado da execução do delito de lavagem de dinheiro, financiamento de terrorismo e suborno a funcionários públicos nacionais e estrangeiros. Estabelece ainda, que as empresas necessitam agir preventivamente por meio da criação de órgáos consultivos e deliberativos no combate aos crimes econômicos.

Em Portugal, no artigo $11^{\circ}$ do Código Penal determina que somente as pessoas físicas podem cometer crimes, salvo disposiçấo legal expressa em contrário. Logo, existem dois atos normativos no ordenamento jurídico português que estabelece a imputação criminal dos entes jurídicos. O primeiro é o decreto-lei número 28 de 1984, que seguindo as 
recomendaçôes do Conselho Europeu tipifica a imputação penal das pessoas coletivas que infrinjam a ordem econômica e a saúde pública. Outra lei extravagante que determina a responsabilidade criminal das pessoas jurídicas é a de número 109/91, chamada de lei da criminalidade da informática.

$\mathrm{Na}$ França, com o crescimento da nova ordem econômica mundial os juristas franceses foram agregando conhecimentos e paulatinamente reintroduziram o princípio societas delinquere potest. Com a entrada em vigor no ano de 1995 do atual Código Penal, mais especificamente, nos artigos 121 e 122, a França juntou-se ao rol dos países que admitem a responsabilidade penal das pessoas jurídicas, sempre que o crime for cometido por seus representantes ou órgãos e no interesse da instituição e atentem gravemente à saúde pública, ao meio ambiente e a ordem econômica.

Destaca-se que os preceitos portugueses e franceses influenciaram fortemente as feituras das legislaçóes brasileiras sobre o tema.

No país berço da Revolução Industrial, a Inglaterra, após a nova fase do sistema capitalista onde as indústrias passaram a ser a força motriz da sociedade, as Câmaras Criminais (Criminal Justice Act) passaram a aplicar sanções aos entes coletivos, já que as atuações das empresas mudaram os conceitos tradicionais ao longo dos anos, inclusive criminal. A jurisprudência inglesa sustenta que os atos e estado mental dos dirigentes das pessoas jurídicas, torna-se os atos e o estado mental da entidade que representam.

Nos Estados Unidos, a regra é a responsabilidade criminal das corporaçôes que está vigente desde 1882 com a promulgação do Código Penal de Nova York. A responsabilização americana é a mais ampla dentre os países de origem Common Law, pois admite a imputação das empresas nas infraçóes dolosas e culposas quando cometidas por um empregado no exercício de suas funçóes, mesmo que a empresa não tenha obtido proveito com o fato delituoso e que seja cometido por funcionário de competência mediana dentro da corporação.

Com relação à legislação espanhola a reforma penal de 1995 implementou em relação à responsabilização das pessoas jurídicas as medidas de seguridad e a investigação envolvendo o actuar en nombre de otro. Assim, não há aplicação psicológica das penas convencionais, mas mecanismos de coaçôes próprios dos entes coletivos, bem como, procurou-se criminalizar individualmente quem atua como administrador de fato ou de direito de uma pessoa jurídica ou em seu nome ou a represente legal ou voluntariamente.

\section{Marco Teórico sobre a Responsabilidade Penal da Pessoa Jurídica}

De acordo com Rocha (2003) a construção teórica da responsabilidade penal da pessoa jurídica é de grande importância para orientar os julgadores na solução do caso concreto. 
As teorias que se destacam são: a teoria da ficção; desenvolvida pelo Direito romano-germânico, sendo para a maioria dos juristas do século XIX o fundamento da noção de personalidade jurídica. Também chamada de teoria da realidade, fora instituída por Savigny, segundo afirma que as entidades possuem existência irreal adquirida por meio de liberalidade do Estado, onde não possuem conduta delituosa por não trazerem consigo a vontade e consciência de realizarem ações ou omissóes típicas. De acordo com os defensores da teoria da ficção, atribui-se um meio jurídico para realizar um interesse geral e, para tanto, passou-se a aceitar que uma pessoa ficta fosse tratada como sendo uma pessoa real apenas para efeitos de comodidade na sociedade, uma típica criação artificial pertinente para o momento. Societas deliquere non potest devido não possuir culpabilidade (elemento psicológico) e muito menos disposição para ser penalizada. Os homens seriam sempre os verdadeiros sujeitos dos crimes cometidos quando representassem as pessoas jurídicas.

Silvia Bacigalupo (2001, p.57-58) explica a teoria da ficção:

Por la tanto, desde este punto de vista sólo puede ser sujeto de derechos el ser humano individual, dado que el Derecho sólo es un medio para proteger la personalidad ética del ser humano, de manera tal que la personalidad jurídica deber ser necesariamente el reflejo de la ética. El ejercicio de derechos no puede ser, de acuerdo con ello, otra cosa que la puesta en marcha de dicha personalidad, es decir, de la voluntad individual en un sentido ético.

Por outra vertente destaca-se a teoria da realidade; teoria orgânica ou teoria da personalidade real, cujos defensores mais evidentes são Otto Gierke e Zitelman e os seus pressupostos são totalmente diferentes da teoria da ficção, pois admitem que as entidades coletivas adquiram uma existência indiscutível. Diferente dos indivíduos que as compóem e caracterizadas por finalidades específicas, a pessoa jurídica pode cometer delitos desde que levado em consideraçáo alguns requisitos especiais em relação às pessoas naturais (societas deliquere potest). Serve o ente coletivo apenas como um instrumento, um escudo, nos planos das pessoas naturais que a comandam. Essa teoria busca afirmar e demonstrar que as instituiçôes não são apenas seres artificiais e abstratos criados pelo Estado por meio de um ato normativo, ao contrário, defende-se que as pessoas jurídicas são seres reais e a sua existência embora não signifique o reconhecimento exatamente igual à de uma pessoa física possuem vontade e consciência própria, podendo inclusive ser responsabilizada e penalizada segundo as normas da Ciência Criminal. "[...] é inescondível que a pessoa jurídica não é uma ficção, mas um verdadeiro ente social que surge da realidade concreta e que não pode ser desconhecido pela realidade jurídica." (SHECAIRA, 1998, p.87).

Assim, foram criadas cinco subcorrentes que serviram de base para a imputação da personalidade das pessoas jurídicas. Quais sejam: biológica, fisiológica, sociológica, institucional e técnica. 
Com relação ao primeiro parâmetro, a biológica, dispóe que as pessoas naturais que compóem as entidades concebem um órgão estruturante e integrado. A pessoa jurídica forma uma realidade natural, resultante da existência de vários membros cada qual com suas funçôes que se complementam, semelhante a um organismo vivo.

Para a teoria fisiológica os indivíduos, ao se associarem, criaram um novo ser, passível de direitos e obrigaçóes perante a sociedade. Forma uma unidade real.

Enquanto que a teoria sociológica, a ideia de responsabilidade jurídica fundamentase na realidade e necessidade social. As entidades coletivas são capazes de influenciar na circulação de riquezas e na participação no desenvolvimento social.

No que se refere à fundamentaçáo institucionalista a partir de certo estágio de sua existência a corporação passa a executar uma função tão peculiar (ação institucional), que a torna uma pessoa corporificada plena para exigir direitos e cumprir obrigaçóes no meio social.

Por fim, a concepção da realidade técnica, diz que a pessoa física utiliza-se da pessoa jurídica para alcançar os seus propósitos, caracteriza-se por possuir uma natureza instrumental.

Observa-se que as correntes que reconhecem a personalidade jurídica não podem atuar isoladamente, ao contrário, se complementam, pois, na proporção que indivíduos se unem para tornarem-se sujeitos de direitos e obrigaçóes irão desempenhar atividades precípuas e todas as conseqüências advindas de suas decisóes atingem a todos que compóem o órgão coletivo. Cada sociedade a partir dos seus atos normativos disciplina a necessidade ou não da existência da personalidade das pessoas jurídicas, e isso com base em uma realidade social estável. E finalmente, para disciplinar os propósitos das pessoas jurídicas se faz mister a criação de normas reguladoras dos mais diferentes ramos do direito e se for o caso, até mesmo, romper com conceitos considerados clássicos para que se possa adaptar a imputabilidade dos entes coletivos a realidade da sociedade.

Mesmo para aqueles que aceitam a teoria da realidade existe ainda uma divergência quanto ao liame de vontades entre a pessoa natural e a jurídica. Sendo dividida em três modelos ou formas; o primeiro batizado de modelo de acréscimo, consiste na exigência de uma dupla imputação, ou seja, a pessoa jurídica será responsabilizada criminalmente por "ricochete" quando houver também uma responsabilização da pessoa física. Trata-se do modelo utilizado pelo Superior Tribunal de Justiça (STJ) e pela lei brasileira de número $9.605 / 98$.

De acordo com o modelo chamado de primário ou original, defende que a pessoa jurídica deve ser penalizada pelo ilícito penal independentemente da conduta de seus administradores. 
Por último, o modelo da responsabilização por evento, que consiste em defender que a atividade do ente coletivo é um risco social permanente e a ocorrência de um delito torna-se passível a aplicação da penalidade. Da mesma maneira como no modelo primário existe uma independência entre a punibilidade dos dirigentes e da pessoa jurídica. Sistema adotado recentemente pelo Supremo Tribunal Federal (STF).

Helena da Costa (2010) defende que o ente coletivo seja penalizado independentemente da conduta da pessoa natural por se tratarem de responsabilidades heterogêneas e independentes.

Logo, essas correntes teóricas apesar de divergirem em alguns pontos são de suma importância para os embasamentos das jurisprudências dos tribunais brasileiros, já que a temática não é pacífica e está de longe de ser resolvida.

\section{Responsabilidade Penal da Pessoa Jurídica: Questão Controvertida}

A doutrina controverte-se em torno da responsabilização das corporaçóes aos delitos causados no meio ambiente, e surgiram, de um lado, correntes que pregavam estar finalmente incorporada em nosso Direito (societas deliquere potest), e, de outro, correntes para as quais jamais admitiram essa forma de imputação (societas deliquere non potest).

Fiorillo (2002, p.47) enfatiza a grande controvérsia sobre o tema abordado:

Muita controvérsia foi trazida também. Ademais deve ser ressaltado que a responsabilidade penal da pessoa jurídica não é aceita de forma pacífica. Pondera-se que não há como conceber o crime sem um substractum humano. Na verdade, o grande inconformismo da doutrina penal clássica reside na inexistência da conduta humana, porquanto esta é da essência do crime. Dessa forma, para aqueles que não admitem crime sem conduta humana, torna-se inconcebível que a pessoa jurídica possa cometê-lo (grifo no original)

Com a feitura da legislação brasileira número 9.605/98, que prevê a responsabilidade penal das corporaçóes por crimes ambientais, os debates acerca de sua constitucionalidade de processar e condenar criminalmente uma entidade por crime ambiental mostra-se cada vez mais discutidos. No grupo de juristas favoráveis, defende Machado (1998, p. 591-592) o seguinte:

A sanção do crime ambiental e a sanção administrativa no tocante à pessoa jurídica guardam quase uma igualdade. A necessidade de se trazer para o processual penal a matéria ambiental reside principalmente nas garantias funcionais do aplicador da sanção. O Poder Judiciário, a quem caberá aplicar a sanção penal contra a pessoa jurídica, ainda tem garantias que o funcionário ou o empregado da Administração indireta não possuem ou deixaram de ter. 
A experiência brasileira mostra uma omissão enorme da Administração Pública na imposição de sançôes administrativas diante das agressôes ambientais. A possibilidade de serem responsabilizadas penalmente as pessoas jurídicas não irá desencadear uma frenética persecução penal contra empresas criminosas. Tentar-se-à, contudo, impor um mínimo de corretivo, para que a nossa descendência possa encontrar um planeta habitável.

Por outro lado, existem alguns estudiosos que rebatem de forma crítica e totalmente contrária à viabilidade da responsabilização da pessoa jurídica. "A concepção simplista da responsabilidade penal da pessoa jurídica é inconstitucional, ilegal e, de fato, inaplicável." (MORAES, 2002, p.152).

Verifica-se, então, que a problemática que gira em torno do tema da responsabilidade penal da pessoa jurídica é altamente polêmica entre os juristas, por isso a importância de seu estudo e discussão, principalmente quando envolverem questóes ambientais.

\section{Da Culpabilidade da Pessoa Jurídica}

A pesquisa sobre a culpabilidade iniciou na Itália, contudo, foi na doutrina alemã que as definiçôes estruturais se tornaram mais consistentes.

Os estudos sobre o juízo de reprovação foram visíveis, mas somente com o surgimento do sistema finalista o conceito de culpabilidade aperfeiçoou-se. Com a teoria da ação final, a mais adotada no mundo, expóe que além da imputabilidade o agente deveria possuir uma atividade final, uma intenção genuína do ente humano. Com isso somente a pessoa natural poderia realizar conduta, já que é dotada de vontade, consciência e previsibilidade. A culpabilidade agora é um dos requisitos do crime como o fato típico e a ilicitude. Teoria criada na Alemanha por Hans Wezel na década de 30 passou a investigar a pureza da conduta humana. A ação passou a ter um novo conceito ontológico. Atualmente o dolo e a culpa não podem mais serem analisados em sede de culpabilidade, mas no fato típico do delito. A culpabilidade passa a ser constituída pela imputabilidade, a potencial consciência da ilicitude do fato e a exigibilidade de conduta diversa. Dessa maneira, conceitua-se a culpabilidade como a reprovação do agente criminoso pela realização de sua conduta típica e ilícita, quando poderia ter agido de acordo com os ensinamentos da ordem jurídica. Traduz-se em um juízo de reprovação personalíssimo.

Apesar da teoria finalista da ação ter inovado totalmente a teoria do delito náo satisfaz por completo os anseios da sociedade contemporânea, pois resumir à capacidade de ação a conduta somente humana é algo obsoleto e restrito. Os crimes atuais abrangem danos de maiores proporçóes e mecanismos inovadores, com isso as teorias possuem a obrigação de se adaptarem a essas novas realidades sociais. Hoje, os bens jurídicos a serem penalmente 
protegidos ingressam diretamente numa ordem coletiva, como a ordem financeira e o meio ambiente, e não mais somente individual. Não significa o fim do finalismo, mas que poderá ser complementada e modernizada por outras teorias que venham a surgir.

A culpabilidade não pode mais estacionar em preceitos que não preenchem adequadamente as necessidades da realidade atual, que anseia por novos dogmas penais. $\mathrm{O}$ preceito culpável é o termômetro da evolução da Ciência Criminal, logo deve ser sempre avaliado se o seu conceito usual está de acordo com as carências sociais do momento.

Recentemente na década de 70 nasceu à teoria do funcionalismo, cujas bases estão presentes na teoria sistêmica de Niklas Luhmann ${ }^{1}$. O funcionalismo é um uma teoria totalmente inovadora que ao longo dos anos vem agregando vários adeptos especialmente na Europa. Tese desenvolvida por Claus Roxin, que mais tarde foi aprimorado por Jakobs, prega em seus fundamentos um método teleológico, onde se visa à funcionalidade do Direito Penal. Uma apuração menos ontológica do crime que prega a política criminal como método preventivo de paz social. Quer-se com o funcionalismo delimitar principalmente a importância da finalidade da pena como forma de prevenção geral positiva. Possui como alicerces a teoria da imputação objetiva e a extensão da culpabilidade para a categoria de responsabilidade. Fundamentos doutrinários bastantes revolucionários e com um alto grau de aplicabilidade prática.

$\mathrm{Na}$ teoria funcionalista a ação é totalmente dependente dos pressupostos jurídicos da imputação, e a culpabilidade é uma forma de prevenção social, enquanto que a pena funciona como o restaurador da estabilidade normativa. Critérios imprescindíveis para solidificar a responsabilidade penal da pessoa jurídica.

Para alguns, totalmente avessos a mudanças, não se pode falar em culpabilidade da pessoa jurídica à medida que esta não tem uma omissão ou agir independente, movido por ato volitivo íntimo, é dizer, uma conduta humana precípua. É pacífico que, quem não possui vontade, pressuposto do dolo na teoria tradicional do delito, não pode cometer delitos. Predomina o entendimento de que pessoa jurídica não tem vontade própria e isso é uma das razóes pelas quais respeitáveis doutrinadores não aceitam sua responsabilidade penal, pois lhe falta um pressuposto básico e essencial, a conduta, ou melhor, o agir, a intenção, a finalidade.

Porém, o entendimento que vem tomando corpo perante os penalistas modernos acerca da culpabilidade da pessoa jurídica é aquele segundo o qual não se aplica ao ente coletivo o mesmo conceito de culpabilidade usual as pessoas naturais, medindo-a, nesses

1 A teoria sistêmica afirma que o sistema jurídico é nada mais do que um subsistema social global. As normas são estruturas de expectativas simbólicas generalizadas, cuja função é estabilizar o próprio sistema. Um sistema se produz e reproduz por si mesmo, por meio da autopiose, contudo, apesar de ser fechado pode interagir com o ambiente, sem estar a este totalmente vinculado. 
casos, de acordo com a sua capacidade de atribuição. O crime é imputado à pessoa jurídica quando houver, na prática do delito, interesse institucional precípuo, o qual se verifica por meio do interesse econômico que o gerou.

A pessoa jurídica não pratica condutas criminosas, ela desenvolve atividades próprias, uma verdadeira conduta institucional.

No desenvolvimento de suas atividades pode o ente coletivo vir a agredir o bem jurídico e a agressão é consequência do interesse da instituição na obtenção de proveito financeiro, ou melhor, de sua responsabilização. E essa capacidade está para a responsabilização penal da pessoa jurídica, assim como, a culpabilidade está para a responsabilidade criminal da pessoa física.

Seria uma forma inovadora de imputação penal, já que mudaria totalmente a forma clássica que vem sendo adotado com a conduta finalista da pessoa física. Agora os criminalistas poderiam enquadrar a conduta, até então considerada impossível, da pessoa jurídica e a lei penal apenas como base na pretensão econômica que é praticada e que veio direta e especificamente a violar os axiomas sociais. As características da culpabilidade do ente coletivo e da pessoa natural são divergentes, porém se completam.

De acordo com a responsabilização penal da pessoa jurídica de forma diferenciada o doutrinador espanhol Muñoz-Conde explica:

Desde el punto de vista de un Derecho penal que en la configuración de la infracción delictiva parte de la acción humana, de la culpabilidad y de unos presupuestos psicológicos que solo pueden predicarse de la persona física individual, se hace difícil admitir a responsabilidad de entes fictícios como son las personas jurídicas.

También el sistema de sanciones aplicables, penas o medidas, descansa en unos presupuestos psicológicos individuales, culpabilidad-peligrosidad, en función de las cuales se asigna al sistema de sanciones unas finalidades de prevención general o especial que difícilmente pueden lograrse en el ámbito de las personas jurídicas.

Pero, éste no quiere decir que el Ordenamiento jurídico en su conjunto deba permanecer impasible ante los abusos que a través de la persona jurídica se comentan y que, cuando esos abusos revistan los caracteres de delito, no pueda imponer consecuencias que específicamente incidan en la persona jurídica que sirvió de vehículo o instrumento para su comisión.

Hay que buscar, pues, la sanción adecuada a estos entes jurídicos, pura creación artificial del Derecho, que tan importante actividad despliegan en el actual mundo económico.

Personalmente, me parece bien que el actual Derecho penal disponga de un arsenal de medios específicos de reacción y control jurídicopenal de 


\section{las personas jurídicas. Claro que estos medios deben ser adecuados a la propia naturaleza de estos entes ${ }^{2}$. (grifo nosso)}

Torna-se fundamental a responsabilização criminal de qualquer pessoa física ou jurídica que cometa delito, e é claro, atendendo a peculiaridade da culpabilidade de cada ser. Ao responsabilizar a pessoa moral devem-se adotar critérios diferentes com relaçáo à pessoa natural, rompendo, portanto, com os conceitos clássicos da dogmática antropocêntrica penal e aplicando conceitos inovadores com base em uma culpabilidade especial. "Sin embargo, la identidad de la persona jurídica, a diferencia de la persona natural, no se determina a partir de la conciencia sino a partir de la unidad de su constitución.” (JAKOBS, 2004, p.62).

E ainda, Kurt Seelmann (2004, p.37) ensina:

Una variante de este argumento de compatibilidad va por la línea que busca desarrollar para las empresas un concepto especial de culpabilidad ajustado a ellas. Mientras que los sujetos individuales puede reprochárseles no haber percibido suficientemente su propia responsabilidad, a las empresas puede reprochárseles una organización administrativa defectuosa. Los conflictos referidos a las personas naturales y los referidos a personas jurídicas podrían resolverse, por tanto, de manera separada en vías distintas de Derecho penal de la culpabilidad, cada cual con presupuestos propios de imputación.

Insta acentuar, que a pessoa jurídica não comete crime, apenas é responsabilizada objetivamente (risco social) por uma conduta subjetiva realizada pela pessoa física, que atua em seu nome e criou o ente coletivo para uma finalidade específica. "Deve-se reconhecer que tal disposição não estabelece que a pessoa jurídica seja autora, mas apenas responsável.” (ROCHA, 2003, p.70)

A imputação criminal do ente jurídico não obedece a uma caracterização subjetiva, mas sim objetiva, pois inicialmente analisa os elementos clássicos do fato típico realizada pela pessoa natural com víeis subjetivo, para em seguida enquadrar a responsabilidade penal da pessoa jurídica. Nesse caso não se relaciona a presunção de dolo ou culpa e sim o surgimento do relevante risco (ameaça predisposta) e o prejuízo ao bem jurídico ecológico protegido por uma política criminal.

David Goldblatt (1996, p.231) ao mencionar Ulrich Beck relata sobre as características dos riscos ambientais na sociedade contemporânea e a necessidade de uma política de controle:

2 Los delitos patrimoniales y económicos. Disponível em <http://www.cienciaspenales.net/descargas/ idp_docs/doctrinas/los $\% 20$ delitos $\% 20$ patrimoniales $\% 20 \mathrm{y} \% 20$ economicos $\% 20$ munoz $\% 20$ conde. pdf $>$. Acesso em: 20 de abr. 2015. 
Embora Beck utilize as ideia de riscos e perigos para se referir a muitas áreas de vida social, estas ideias são analisadas mais minuciosamente na equação dos riscos e perigos relativamente à degradação do ambiente. Naturalmente que certos perigos e azares sempre ameaçaram as sociedades humanas. $\mathrm{O}$ motivo por que passam a ser riscos, como Giddens referiu, é o facto de serem perigos e azares que são conhecidos, cuja ocorrência pode ser prevista e cuja probabilidade pode ser calculada. Correr perigo é uma coisa. Saber que se está em perigo é completamente diferente. Saber que se está em perigo e sentir-se completamente impotente para alterar o curso dos acontecimentos que causam esse perigo é ainda outra coisa. Juntamente com a alteraçáo de perigo para risco, os problemas ecológicos contemporâneos possuem outras características diferentes que evocam e exigem formas muito determinadas de resposta política e psicológica. Estas exigências e respostas são de tal dimensão que pode dizer-se que a sua emergência anuncia a emergência de uma forma de modernidade diferente.

Merece esclarecer que a responsabilização objetiva não abandona a teoria finalista da ação totalmente, alguns elementos serão conservados e outros melhorados, contudo, surge uma nova forma de proteção penal mais enriquecida. $\mathrm{O}$ intuito desse enquadramento objetivo é viabilizar a aplicação da teoria do delito, quanto à construção de um ato normativo anterior que tutele o bem jurídico, cuida-se de uma obrigação explicitamente típica.

$\mathrm{Na}$ ideia de Jesus (2000) a responsabilidade objetiva tem como fundamento os valores sociais que a política penal deseja tutelar.

Não se trata de concursos de agentes criminosos, em que a pessoa física e a jurídica sejam co-autoras de determinado delito, pois nesse caso será necessário um levantamento de culpa ou dolo dos autores para saber até onde os agentes tinham o domínio do fato e consequentemente atenderem o enquadramento legal. Logo, estaria atribuindo uma conduta subjetiva extensiva aos entes coletivos, o que é inconcebível.

A responsabilidade da corporação deve obedecer a certos requisitos, dentre os quais: deliberaçáo no âmbito da pessoa jurídica por prepostos com poderes de representação; autor material vinculado em nome e benefício da pessoa jurídica; amparo no poder econômico do ente; a conduta delitiva da pessoa física materialize a atividade institucional e que as atividades desenvolvidas pela pessoa jurídica dissimulem a sua verdadeira intenção econômica.

Sem dúvida, a culpabilidade e a aplicação da pena tornam-se os pontos chaves para o questionamento da imputabilidade penal das pessoas jurídicas, pois segundo a doutrina clássica a culpabilidade é o pressuposto da aplicação da pena. No entanto, faz-se necessária a inovação da dogmática penal para que se possa lograr êxito na imputação penal das pessoas jurídicas. "Para culpar criminalmente una entidad colectiva tendrá que modificar y crear nuevos conceptos dogmáticos." (SOARES, 2013, p.69). 
É dizer, existe a possibilidade de responsabilização penal da pessoa jurídica, para tanto, será imprescindível a quebra de paradigmas. Mutatis mutandis, em busca de uma maior proteção aos bens jurídicos considerados essenciais.

\section{Os Posiconametos do STF e do STJ quanto a Responsabilização das Pes- soas Jurídcas por Crimes Ambientais}

No Brasil a questão ambiental tomou um grande corpo com a Constituição Federal de 1988, pois até então as normas que protegiam o meio ambiente eram ineficazes e serviam apenas como um paliativo para um problema que crescia a todo instante. Pela primeira vez na sua história a Constituição brasileira no seu título VIII, da ordem social, mais precisamente no artigo 225 , seus incisos e parágrafos prevêem especificamente inúmeras políticas ambientais. Reza o texto que todos os cidadáos têm direito a um meio ambiente ecologicamente equilibrado, de uso comum do povo e fundamental a sua vida. Impóe ainda ao Estado o dever de assegurar à coletividade e as futuras geraçóes a defesa e preservação ambiental.

Sem dúvida, o assunto na seara constitucional e ambiental que trouxe mais discussões está expresso no artigo $225, \$ 3^{\circ}$, que responsabiliza a conduta e atividades consideradas lesivas ao meio ambiente, onde seus infratores pessoas físicas ou jurídicas estaráo sujeitas a sançôes penais, administrativas e civis. Corroborando com essa premissa o artigo $173, \$ 5^{\circ}$ estabelece que as pessoas jurídicas independente da responsabilidade individual dos dirigentes serão responsáveis por atos praticados contra a ordem econômica, financeira e contra a economia popular.

Após a previsão constitucional, surgiu em 12 de fevereiro de 1998 a lei de número 9.605, no qual objetivo é a disposição sobre as sançôes penais e administrativas derivadas de condutas e atividades lesivas ao meio ambiente, além de outras providências. Apesar das críticas a lei ambiental brasileira é considerada pela maioria dos estudiosos um enorme avanço no que se refere à tutela ambiental e penal.

O Superior Tribunal de Justiça (STJ) ao longo dos últimos anos adotou a teoria societas delinquere potest, é dizer, a pessoa coletiva poderá sim ser responsabilizada por crimes ambientais, desde que haja a intervenção direta do responsável pela pessoa jurídica na agressão ambiental. As primeiras decisões dessa corte superior causaram muitas controvérsias e discussóes, mesmo com a previsão constitucional e legal explícita.

A culpabilidade do ente jurídico possui como base uma responsabilidade social que o mesmo desempenha desde que o preposto pratique uma conduta danosa em nome e em razão da atividade da pessoa jurídica, além do mais, é plenamente possível uma imputação para a pessoa física (conduta subjetiva) e outra para a entidade coletiva (conduta objetiva de risco social), mas sempre com alto grau de interdependência. 
Para responsabilizar os entes coletivos por delitos que venham a ocorrer na esfera ambiental há uma necessidade de inovação nos conceitos tradicionais da teoria do delito, principalmente no que se refere à culpabilidade e a aplicação das penas.

O uso de preceitos dogmáticos penais inovadores, decorrente das novas necessidades sociais, fez com que o Direito Penal de hoje não se preocupasse somente com a tutela individual, mas também com a proteção de direitos difusos e coletivos. A imputação penal das pessoas jurídicas se enquadra perfeitamente nessa nova era da Ciência Criminal. Assim é a lição do STJ no início da década:

PROCESSO RESP 564960 / SC RECURSO ESPECIAL

RELATOR; MINISTRO GILSON DIPP (1111)

ÓRGÁO JULGADOR: T5 - QUINTA TURMA

DATA DO JULGAMENTO: 02/06/2005

DJ 13/06/2005 P. 331RDR VOL. 34 P. 419

EMENTA: CRIMINAL. CRIME AMBIENTAL PRATICADO POR PESSOA JURÍDICA. RESPONSABILIZAÇÃO PENAL DO ENTE COLETIVO. POSSIBILIDADE. PREVISÃO CONSTITUCIONAL REGULAMENTADA POR LEI FEDERAL. OPÇÁO POLÍTICA DO LEGISLADOR. FORMA DE PREVENÇÁO DE DANOS AO MEIO-AMBIENTE. CAPACIDADE DE AÇĀO. EXISTÊNCIA JURÍDICA. ATUAÇĀO DOS ADMINISTRADORES EM NOME E PROVEITO DA PESSOA JURÍDICA. CULPABILIDADE COMO RESPONSABILIDADE SOCIAL. CO-RESPONSABILIDADE. PENAS ADAPTADAS À NATUREZA JURÍDICA DO ENTE COLETIVO. RECURSO PROVIDO.

I. Hipótese em que pessoa jurídica de direito privado, juntamente com dois administradores, foi denunciada por crime ambiental, consubstanciado em causar poluição em leito de um rio, através de lançamento de resíduos, tais como, graxas, óleo, lodo, areia e produtos químicos, resultantes da atividade do estabelecimento comercial.

II. A Lei ambiental, regulamentando preceito constitucional, passou a prever, de forma inequívoca, a possibilidade de penalização criminal das pessoas jurídicas por danos ao meio-ambiente.

III. A responsabilização penal da pessoa jurídica pela prática de delitos ambientais advém de uma escolha política, como forma não apenas de puniçáo das condutas lesivas ao meio-ambiente, mas como forma mesmo de prevenção geral e especial.

IV. A imputação penal às pessoas jurídicas encontra barreiras na suposta incapacidade de praticarem uma ação de relevância penal, de serem culpáveis e de sofrerem penalidades. 
V. Se a pessoa jurídica tem existência própria no ordenamento jurídico e pratica atos no meio social através da atuação de seus administradores, poderá vir a praticar condutas típicas e, portanto, ser passível de responsabilização penal.

VI. A culpabilidade, no conceito moderno, é a responsabilidade social, e a culpabilidade da pessoa jurídica, neste contexto, limita-se à vontade do seu administrador ao agir em seu nome e proveito.

VII. A pessoa jurídica só pode ser responsabilizada quando houver intervenção de uma pessoa física, que atua em nome e em benefício do ente moral.

VIII. "De qualquer modo, a pessoa jurídica deve ser beneficiária direta ou indiretamente pela conduta praticada por decisão do seu representante legal ou contratual ou de seu órgão colegiado."

IX. A atuação do colegiado em nome e proveito da pessoa jurídica é a própria vontade da empresa. A co-participação prevê que todos os envolvidos no evento delituoso serão responsabilizados na medida de sua culpabilidade.

X. A Lei Ambiental previu para as pessoas jurídicas penas autônomas de multas, de prestação de serviços à comunidade, restritivas de direitos, liquidação forçada e desconsideração da pessoa jurídica, todas adaptadas à sua natureza jurídica.

XI. Não há ofensa ao princípio constitucional de que "nenhuma pena passará da pessoa do condenado...”, pois é incontroversa a existência de duas pessoas distintas: uma física - que de qualquer forma contribui para a prática do delito - e uma jurídica, cada qual recebendo a punição de forma individualizada, decorrente de sua atividade lesiva.

XII. A denúncia oferecida contra a pessoa jurídica de direito privado deve ser acolhida, diante de sua legitimidade para figurar no pólo passivo da relação processual-penal.

XIII. Recurso provido, nos termos do voto do Relator ${ }^{3}$. (grifo nosso)

Bem como, o ministro relator Paulo Gallotti no mesmo diapasáo decidiu no recurso especial o seguinte:

\author{
PROCESSO - RESP 847476 / SCRECURSO ESPECIAL \\ 2006/0089145-1 \\ RELATOR - MINISTRO PAULO GALLOTTI (1115) \\ ÓRGÃO JULGADOR - T6 - SEXTA TURMA \\ DATA DA PUBLICAÇÁO/FONTE 08/04/2008 DJE 05/05/2008
}

3 Disponível em <http://www.stj.gov.br>. Acesso em: 19 de abr. 2015. 
EMENTA: PENAL. CRIME AMBIENTAL. RESPONSABILIZAÇÁO DA PESSOA JURÍDICA. POSSIBILIDADE. DELITO DO ART. 60 DA LEI No 9.605/1998. PRESCRIÇÃO DA PRETENSÃO PUNITIVA. EXTINÇÁO DA PUNIBILIDADE. RECURSO PREJUDICADO.

1. "Admite-se a responsabilidade penal da pessoa jurídica em crimes ambientais desde que haja a imputação simultânea do ente moral e da pessoa física que atua em seu nome ou em seu benefício, uma vez que não se pode compreender a responsabilização do ente moral dissociada da atuação de uma pessoa física, que age com elemento subjetivo próprio." (REsp $\mathrm{n}^{\circ}$ 889.528/SC, Relator o Ministro Felix Fischer, DJU de 18/6/2007)

2. Sendo de 6 meses de detenção a pena máxima cominada ao crime previsto no art. 60 da Lei no 9.605/1998, com relação à empresa Castilho Prestaçấo de Serviços Ltda, constata-se que já decorreram mais de dois anos desde a data do fato incriminado sem que fosse recebida a inicial acusatória, e, quanto a Luis Vanderlei de Castilhos, o transcurso de mais de dois anos desde o recebimento da denúncia, operando-se, em ambos os casos, a prescrição da pretensão punitiva, nos termos do art. 109, inciso VI, do Código Penal, uma vez que não ocorreu qualquer causa interruptiva desde entâo.

3. Recurso especial parcialmente provido ${ }^{4}$. (grifo nosso)

As decisóes do STJ com base no preceito constitucional rompem com as clássicas teorias do delito da responsabilidade individual subjetiva, pois entende os julgadores que diante da nova conjuntura a Ciência Jurídica deve adaptar-se a essa nova realidade para não promover impunidades. A responsabilidade das entidades coletivas não tem como base a culpa individual, mas sim, uma responsabilidade social que atinge a todos.

Por outro lado, no ano de 2005 o Supremo Tribunal Federal (STF) por meio do ministro Gilmar Mendes, em um julgamento considerado peculiar, do $\mathrm{HC}$ de número 83554 , dissociou a conduta da pessoa jurídica e da pessoa natural ao quebrar os seus nexos intersubjetivos. Diz a jurisprudência:

HC 83554 / PR - PARANÁ

RELATOR (A): MIN. GILMAR MENDES

JULGAMENTO: 16/08/2005

ÓRGÁO JULGADOR: SEGUNDA TURMA.

PUBLICAÇÁO DJ28-10-2005 PP-00060 EMENT VOL-02211-01 PP-00155 RTJ VOL-00209-01 PP-00186. LEXSTF V. 27, N. 324, 2005, p. 368-383

4 Disponível em <http://www.stj.gov.br>. Acesso em: 19 de abr. 2015. 
EMENTA: Habeas Corpus. 2. Responsabilidade penal objetiva. 3. Crime ambiental previsto no art. $2^{\circ}$ da Lei no 9.605/98. 4. Evento danoso: vazamento em um oleoduto da Petrobrás 5. Ausência de nexo causal. 6. Responsabilidade pelo dano ao meio ambiente não-atribuível diretamente ao dirigente da Petrobrás. 7. Existência de instâncias gerenciais e de operação para fiscalizar o estado de conservação dos 14 mil quilômetros de oleodutos. 8. Não-configuração de relação de causalidade entre o fato imputado e o suposto agente criminoso. 8. Diferenças entre conduta dos dirigentes da empresa e atividades da própria empresa. 9. Problema da assinalagmaticidade em uma sociedade de risco. 10. Impossibilidade de se atribuir ao indivíduo e à pessoa jurídica os mesmos riscos. 11. Habeas Corpus concedido5 . (grifo nosso)

Em 19 de agosto de 2008, ao julgar o HC 92921, o ministro relator Ricardo Lewandowski, torna a esboçar mais uma vez a preponderância dos conceitos clássicos da dogmática penal em relação aos modernos conceitos da imputação criminal coletiva:

HC 92921 / BA - BAHIA HABEAS CORPUS

RELATOR (A): MIN. RICARDO LEWANDOWSKI

JULGAMENTO: 19/08/2008 ÓRGÁO JULGADOR: PRIMEIRA TURMA

PUBLICAÇĀO: DJE-182 DIVULG 25-09-2008 PUBLIC 26-09-2008

EMENTA: PENAL. PROCESSUAL PENAL. CRIME AMBIENTAL. HABEAS CORPUS PARA TUTELAR PESSOA JURÍDICA ACUSADA EM AÇÃO PENAL. ADMISSIBILIDADE. INÉPCIA DA DENÚNCIA: INOCORRÊNCIA. DENÚNCIA QUE RELATOU A SUPOSTA AÇÃO CRIMINOSA DOS AGENTES, EM VÍNCULO DIRETO COM A PESSOA JURÍDICA CO-ACUSADA. CARACTERÍSTICA INTERESTADUAL DO RIO POLUÍDO QUE NÁO AFASTA DE TODO A COMPETÊNCIA DO MINISTÉRIO PÚBLICO ESTADUAL. AUSÊNCIA DE JUSTA CAUSA E BIS IN IDEM. INOCORRÊNCIA. EXCEPCIONALIDADE DA ORDEM DE TRANCAMENTO DA AÇÃO PENAL. ORDEM DENEGADA.

I - Responsabilidade penal da pessoa jurídica, para ser aplicada, exige alargamento de alguns conceitos tradicionalmente empregados na seara criminal, a exemplo da culpabilidade, estendendo-se a elas também as medidas assecuratórias, como o habeas corpus.

II - Writ que deve ser havido como instrumento hábil para proteger pessoa jurídica contra ilegalidades ou abuso de poder quando figurar como co-ré em ação penal que apura a prática de delitos ambientais, para os quais é cominada pena privativa de liberdade. [...]

5 Disponível em <http://www.stf.gov.br>. Acesso em: 19 de abr. 2015. 
VII - Ordem denegada. Decisão A Turma, preliminarmente, por maioria de votos, deliberou quanto à exclusão da pessoa jurídica do presente habeas corpus, quer considerada a qualificaçáo como impetrante, quer como paciente; vencido o Ministro Ricardo Lewandowski, Relator. No mérito, por unanimidade, indeferiu a ordem ${ }^{6}$. (grifo nosso)

Dessa maneira, embora o STF não tenha decidido sobre o mérito do tema da responsabilidade penal da pessoa jurídica demonstrava até a referida data uma visão inicialmente antropocêntrica com fulcro na diferenciação da responsabilidade entre a pessoa jurídica e a pessoa física, e conseqüentemente na exclusão dos entes coletivos da imputação criminal.

Náo obstante, em 2013, o STF passou a inovar os entendimentos anteriores quando julgou no Recurso Extraordinário de número 548181 a possibilidade da responsabilização criminal do ente coletivo, contudo, sob uma ótica diferenciada, já que trabalhou com a linha de imputação penal da pessoa jurídica dissociada da pessoa física. Da seguinte maneira se pronunciou a ministra relatora Rosa Weber:

\section{RE 548181 / PR - PARANÁ RECURSO EXTRAORDINÁRIO}

Relator(a): Min. ROSA WEBER Julgamento: 06/08/2013 Órgáo Julgador: Primeira Turma Publicaçáo

ACÓRDÁO ELETRÔNICO DJe-213 DIVULG 29-10-2014 PUBLIC 30-10-2014

EMENTA RECURSO EXTRAORDINÁRIO. DIREITO PENAL. CRIME AMBIENTAL. RESPONSABILIDADE PENAL DA PESSOA JURÍDICA. CONDICIONAMENTO DA AÇÁO PENAL À IDENTIFICAÇÃO E À PERSECUÇÃO CONCOMITANTE DA PESSOA FÍSICA QUE NÁO ENCONTRA AMPARO NA CONSTITUIÇÂO DA REPÚBLICA.

1. $\mathrm{O}$ art. $225, \$ 3^{\circ}$, da Constituição Federal não condiciona a responsabilização penal da pessoa jurídica por crimes ambientais à simultânea persecução penal da pessoa física em tese responsável no âmbito da empresa. A norma constitucional náo impóe a necessária dupla imputaçáo. 2. As organizaçóes corporativas complexas da atualidade se caracterizam pela descentralização e distribuição de atribuiçóes e responsabilidades, sendo inerentes, a esta realidade, as dificuldades para imputar o fato ilícito a uma pessoa concreta. 3. Condicionar a aplicaçáo do art. 225, $\$ 3^{\circ}$, da Carta Política a uma concreta imputaçáo também a pessoa física implica indevida restriçáo da norma constitucional, expressa

6 Disponível em <http://www.stf.gov.br>. Acesso em: 19 de abr. 2015. 
a intençáo do constituinte originário náo apenas de ampliar o alcance das sançóes penais, mas também de evitar a impunidade pelos crimes ambientais frente às imensas dificuldades de individualização dos responsáveis internamente às corporaçóes, além de reforçar a tutela do bem jurídico ambiental. 4. A identificaçấo dos setores e agentes internos da empresa determinantes da produção do fato ilícito tem relevância e deve ser buscada no caso concreto como forma de esclarecer se esses indivíduos ou órgãos atuaram ou deliberaram no exercício regular de suas atribuiçôes internas à sociedade, e ainda para verificar se a atuação se deu no interesse ou em benefício da entidade coletiva. Tal esclarecimento, relevante para fins de imputar determinado delito à pessoa jurídica, não se confunde, todavia, com subordinar a responsabilização da pessoa jurídica à responsabilização conjunta e cumulativa das pessoas físicas envolvidas. Em não raras oportunidades, as responsabilidades internas pelo fato estarão diluídas ou parcializadas de tal modo que não permitirão a imputaçáo de responsabilidade penal individual. 5. Recurso Extraordinário parcialmente conhecido e, na parte conhecida, provido 7 . (grifo nosso)

Com esse entendimento a Suprema Corte brasileira surpreende positivamente com sua última decisão, no entanto, surge a crítica da corrente teórica aplicada. O modelo de acréscimo, o qual é defendido pelo STJ, é o que possui maior viabilidade prática, já que se torna impossível e até prejudicial ao mecanismo jurídico dissociar a conduta subjetiva da pessoa física da conduta objetiva da corporação. Apesar de serem diferentes as condutas possuem um nexo causal inseparável e interdependente.

\section{Penalogia}

A aplicação de penas aos agentes criminosos enseja maior estabilidade normativa, traz uma valorizaçáo à ordem jurídica como forma de combate aos problemas sociais. O Estado, instituição competente na tutela dos valores da sociedade, deve preocupar-se principalmente com medidas preventivas no que se refere aos bens ecológicos, pois o meio ambiente depois de ser prejudicado não restaura as suas condiçóes anteriores. Como também, implementar sançóes reparadoras, rápidas e enérgicas. "Quanto mais a pena for rápida e próxima do delito, tanto mais justa e útil será.” (BECCARIA, 1999, p.79).

As penalidades, desse modo, devem causar efeitos preventivos, retributivos e restauradores a qualquer pessoa que cometa crime ambiental.

O crime avança sobre a natureza e as empresas são as maiores responsáveis, logo não podem ficar impunes diante de tais atos danosos.

7 Disponível em <http://www.stf.gov.br>. Acesso em: 19 de abr. 2015. 
A tendência atual é que todas as pessoas, físicas ou jurídicas, que atentem contra a ordem jurídica penal sejam consideradas culpadas e passíveis de penas, mesmo que para isso, seja obrigatória a modificação de alguns conceitos penais tradicionais, como a teoria da culpabilidade e da aplicação da pena.

Na visão de Machado (1998) adotar apenas a previsão da responsabilidade penal da pessoa física diante dos delitos ambientais é coadunar com a ineficácia do Direito Penal diante dos danos ecológicos.

Para que o ente coletivo possa sofrer a punibilidade que lhe seja atribuída as Ciências Criminais terão que se adaptarem as novas situaçóes sociais, contudo isso não quer dizer que os conceitos tradicionais seráo abolidos totalmente, mas sim apenas encaixados em uma nova realidade. $\mathrm{O}$ que náo pode acontecer é que as pessoas jurídicas fiquem impunes servindo de imunidade para os seus dirigentes causarem lesôes aos bens ecológicos.

A lei Ambiental brasileira, número 9.605/98, inovou também no que se refere aos tipos de sançôes aplicáveis as pessoas jurídicas, pois observou critérios importantes como o grau de culpabilidade dos diretores e funcionários das entidades.

As penas aplicáveis às pessoas jurídicas podem ser as seguintes: a pena de multa, suspensão parcial ou total das atividades, interdição temporária, proibição de contratar com o poder público, prestação de serviços à comunidade, liquidação forçada e a desconsideração da personalidade jurídica.

O jurista David Baigún (2000, p.273-274) defende que no momento da dosimetria da pena o julgador deve observar critérios inerentes a pessoa jurídica:

No obstante estos diferentes niveles, el concepto de determinación es unitario, los factores que concurren para la valoración están presentes, tanto en la consideración general (primer nivel), en el encuadramiento legal (segundo nivel) como en el aspecto más focalizado de la personalización (tercer nivel). Como veremos después, estos factores son de distinta naturaleza, carecen de homogeneidad, por lo cual resulta harto riesgoso el intento de clasificarlos dentro de un plano sistemático; reducido nuestro análisis a los dos niveles que aquí importan (determinación legal y determinación judicial), sólo podemos aspirar a una enunciación $y$, aun así, sin un baremo racional que permita establecer un orden de importancia o de gravitación. Tal vez el único criterio rescatable sea la división entre presupuestos de la determinación y factores de valoración. Entre los primeros se hallan el juicio de responsabilidad social y el marco penal; entre los segundos, el fin corrector de las penas, las medidas de seguridad, la conducta de la persona jurídica en el marco económico y social y el papel de la víctima.

O professor Claus Roxin (2008, p.27-28) afirma de maneira consistente à viabilidade que a aplicação de sançóes as pessoas jurídicas ao dizer o seguinte: 
Porém, as sançôes as pessoas jurídicas desempenharão um grande papel no futuro. Afinal, as formas mais socialmente lesivas da criminalidade econômica e ambiental têm sua origem nas grandes e poderosas empresas; também a venda dos mais diversos produtos lesivos à saúde será um problema cada vez maior para o direito penal. Quando, nestes casos, se realiza um tipo penal, é frequentemente difícil, senão mesmo impossível, descobrir os responsáveis na empresa, pois a responsabilidade distribui-se por várias pessoas, e a culpabilidade de uma delas dificilmente pode ser provada. Também náo se consegue enfrentar de modo eficaz os perigos que emanam de uma grande empresa - p. ex., para o meio ambiente através de punição de um indivíduo substituível.

Pelo contrário, sançóes que se acoplem a uma falha da organizaçáo (independentemente de quem, individualmente, seja culpado), podem ter intensos efeitos preventivos. Elas devem abrange desde consideráveis pagamentos em dinheiro até o fechamento da empresa. Também aquelas sançóes morais, ainda em estágio de desenvolvimento jurídico, não são mais verdadeiras penas; pois estas pressupóem uma ação e culpabilidade imputáveis a uma pessoa individual. Uma pessoa jurídica só pode agir e tornar-se culpável em sentido análogo, através de uma construçáo jurídica. Para tanto, será necessário desenvolver regras especiais de imputaçáo, que não posso discutir mais aprofundamento nos limites deste trabalho.

Minha nona conclusão intermediária é: sançóes a pessoas jurídicas, paralelas à puniçáo dos autores individuais, desempenharáo um grande papel no futuro, no combate à criminalidade de empresas. (grifo nosso)

No entanto, para aqueles que não adotam o entendimento da imputação penal aos entes coletivos (societas deliquere non potest), sustentam a inconstitucionalidade latente no processamento e na aplicação de penas às pessoas jurídicas no Direito brasileiro por ferir princípios fundamentais expressos na Carta Magna, notadamente os princípios do devido processo legal, da individualização e da intranscedência da sanção penal.

Explica Juliano Breda (2010, p.296) sobre a suposta inconstitucionalidade da responsabilização penal da empresa frente à lei ambiental de número 9.605/98:

Em conclusão, em face do alto grau de discricionariedade conferido ao aplicador e da ausência de critérios mínimos de interpretação e conscientização de seu conteúdo, as normas da lei $\mathbf{9 . 6 0 5 / 9 8}$ que estabelecem as sançóes penais às pessoas jurídicas são inconstitucionais, em razão da ofensa aos princípios da máxima taxatividade legal e da certeza ou segurança jurídica, derivados diretamente do princípio constitucional da legalidade, bem como pela infração ao princípio constitucional que determina ao legislador a regulamentação da individualização da pena, tarefa visivelmente não cumprida nesta matéria. (grifo nosso) 
Polemiza ainda mais a discussão Raúl Zaffaroni (2010, p.63) quando expóe a inviabilidade da atual legislação processual penal brasileira em penalizar uma pessoa jurídica:

El proceso penal no es sólo un medio de realización de la ley penal, sino que es al mismo tiempo una garantía para la persona humana; la pena solo puede imponerse mediante el proceso legalmente previsto y nada más. Cualquier pretensión de apartase de ese proceso en detrimento de sus garantías resulta violatoria del principio del debido proceso legal. Por ello, cuando no hay ley procesal aplicable, el juez no puede inventarla ni construirla por analogía partiendo de la ley vigente similar. Ello significa confundir la función del proceso civil con el penal y, en definitiva, confundir el modo de provisión de seguridad jurídica que tiene el derecho civil con el que tiene el derecho penal: para cumplir con las pautas de seguridad jurídica de derecho civil (no dejar ningún conflicto sin resolver), es natural que el derecho procesal civil admita e incluso imponga la integración analógica en caso de que la ley omita regular el procedimiento; para cumplir con las pautas de seguridad jurídica del derecho penal, es natural que el derecho procesal no opere cuando la ley penal no vaya acompañada de las disposiciones legales de naturaleza procesal necesarias para realizarlas y que al mismo tiempo garantizan el principio del debido proceso legal. Por ello, estimo que en actual estado legislativo, las disposiciones concernientes a la responsabilidad penal de las personas jurídicas no son aplicables hasta que se sancionen las normas procesales que permitan su realización. (grifo no original)

Insta acentuar, que a aplicação de sanções às corporações não fere nenhum princípio constitucional, ao contrário, encontra-se fundamentado nas premissas da Carta Magna, pois a responsabilização penal da pessoa jurídica irá penalizar uma ação humana, que usou a atividade do ente moral. Nesse entendimento já se pronunciou o STJ:

PROCESSO: REsP 564960 / SC RECURSO ESPECIAL 2003/0107368-4

MINISTRO: Ministro GILSON DIPP (1111)

ÓRGÁO JULGADOR: T5 - QUINTA TURMA

DATA DO JULGAMENTO: 02/06/2005

DATA DA PUBLICAÇÃO/FONTE: DJ 13/06/2005 p. 331RDR vol. 34 p. 419

EMENTA: CRIMINAL. CRIME AMBIENTAL PRATICADO POR PESSOA JURÍDICA. RESPONSABILIZAÇÃO PENAL DO ENTE COLETIVO. POSSIBILIDADE. PREVISÃO CONSTITUCIONAL REGULAMENTADA POR LEI FEDERAL. OPÇÃO POLÍTICA DO LEGISLADOR. FORMA DE PREVENÇÁO DE DANOS AO MEIO-AMBIENTE. CAPACIDADE DE AÇÃO. EXISTÊNCIA 
JURÍDICA. ATUAÇÃO DOS ADMINISTRADORES EM NOME EPROVEITO DA PESSOA JURÍDICA. CULPABILIDADE COMO RESPONSABILIDADE SOCIAL. CO-RESPONSABILIDADE. PENAS ADAPTADAS À NATUREZA JURÍDICA DO ENTE COLETIVO. RECURSO PROVIDO.

I. Hipótese em que pessoa jurídica de direito privado, juntamente com dois administradores, foi denunciada por crime ambiental, consubstanciado em causar poluiçáo em leito de um rio, através de lançamento de resíduos, tais como, graxas, óleo, lodo, areia e produtos químicos, resultantes da atividade do estabelecimento comercial.

II. A Lei ambiental, regulamentando preceito constitucional, passou a prever, de forma inequívoca, a possibilidade de penalizaçáo criminal das pessoas jurídicas por danos ao meio-ambiente.

III. A responsabilização penal da pessoa jurídica pela prática de delitos ambientais advém de uma escolha política, como forma não apenas de punição das condutas lesivas ao meio-ambiente, mas como forma mesmo de prevenção geral e especial.

IV. A imputaçáo penal às pessoas jurídicas encontra barreiras na suposta incapacidade de praticarem uma açáo de relevância penal, de serem culpáveis e de sofrerem penalidades.

V. Se a pessoa jurídica tem existência própria no ordenamento jurídico e pratica atos no meio social através da atuação de seus administradores, poderá vir a praticar condutas típicas e, portanto, ser passível de responsabilização penal.

VI. A culpabilidade, no conceito moderno, é a responsabilidade social, e a culpabilidade da pessoa jurídica, neste contexto, limita-se à vontade do seu administrador ao agir em seu nome e proveito.

VII. A pessoa jurídica só pode ser responsabilizada quando houver intervençáo de uma pessoa física, que atua em nome e em benefício do ente moral.

VIII. "De qualquer modo, a pessoa jurídica deve ser beneficiária direta ou indiretamente pela conduta praticada por decisáo do seu representante legal ou contratual ou de seu órgáo colegiado.”

IX. A atuaçáo do colegiado em nome e proveito da pessoa jurídica é a própria vontade da empresa. A co-participaçáo prevê que todos os envolvidos no evento delituoso seráo responsabilizados na medida se sua culpabilidade.

X. A Lei Ambiental previu para as pessoas jurídicas penas autônomas de multas, de prestaçáo de serviços à comunidade, restritivas de direitos, liquidaçáo forçada e desconsideraçáo da pessoa jurídica, todas adaptadas à sua natureza jurídica. 
XI. Náo há ofensa ao princípio constitucional de que "nenhuma pena passará da pessoa do condenado...”, pois é incontroversa a existência de duas pessoas distintas: uma física - que de qualquer forma contribui para a prática do delito - e uma jurídica, cada qual recebendo a puniçáo de forma individualizada, decorrente de sua atividade lesiva.

XII. A denúncia oferecida contra a pessoa jurídica de direito privado deve ser acolhida, diante de sua legitimidade para figurar no pólo passivo da relaçáo processual-penal.

XIII. Recurso provido, nos termos do voto do Relator ${ }^{8}$. (grifo nosso)

A pessoa jurídica e a pessoa física possuem culpabilidades distintas, logo são pessoas em que a sua criação e extinção são axiologicamente diferentes, passíveis então de penalidades peculiares de acordo com o seu juízo de reprovabilidade, além do mais, durante a relação jurídica processual penal será sempre dada oportunidade a empresa ré, por meio de seu representante legal, o direito a defesa ampla e ao devido processo legal, semelhante ao que acontece com a pessoa física.

No Código de Processo Penal brasileiro9 o preenchimento de suas lacunas é plenamente possível por meio da analogia (autointegração), dos princípios gerais do direito (heterointegração) e da hermenêutica jurídica, ou seja, se durante o desenrolar da relação jurídica processual penal de uma pessoa jurídica o julgador não encontrar textos legais expressos a respeito poderá se valer das mais variadas formas de aplicaçóes e interpretaçóes da legislação instrumental criminal e constitucional. Por outro rasgo, o que não deve acontecer é o abuso desses elementos operacionais para ferir princípios constitucionais.

Importante observar a razoabilidade dos preceitos da Lei Maior, por que nenhum princípio é mais importante do que outro, todos estão numa mesma escala hierárquica de carga normativa, passíveis de serem analisados e aplicados. Precisa-se harmonizar e coordenar as normas constitucionais, com a finalidade de se evitar perdas axiológicas excessivas. "[...] o principio da concordância prática impóe a coordenaçáo e combinaçáo dos bens jurídicos em conflito de forma a evitar o sacrificio (total) de uns em relaçáo aos outros." (CANOTILHO, 2000, p. 1.188 - grifo no original).

Segundo Iennaco (2010) não haverá desrespeito aos princípios constitucionais da intranscedência e individualização da pena a concepção do Direito Penal moderno caracterizado por uma imputação penal objetiva das pessoas jurídicas em detrimento de um novel problema social, como acontece com outros ramos do Direito.

8 Disponível em <http://www.stj.gov.br>. Acesso em: 19 de abr. 2015.

9 Artigo $3^{\circ}$ A lei processual penal admitirá interpretaçáo extensiva e aplicação analógica, bem como o suplemento dos princípios gerais do direito. 
Não há, portanto, inconstitucionalidade no processo e na aplicação de penas as pessoas jurídicas na legislação do Brasil. Ao contrário, a própria Constituição Federal é clara ao prevê que se devem encontrar mecanismos para uma maior eficácia nas aplicaçóes de sançóes aos crimes ambientais e dentre as determinaçóes está à responsabilidade penal do ente coletivo (artigos $173, \$ 5^{\circ}$ e $225, \$ 3^{\circ}$ ), que fora posteriormente ratificado pelo legislador brasileiro por meio da lei de número 9.605/98.

Outra crítica forte ao sistema de responsabilização criminal dos entes morais é com relação à mitigação da pena individual, ou seja, segundo os opositores, o Estado se preocupa tanto em punir as empresas, em busca da proteção coletiva, que se esquece de criar medidas mais eficazes para coibir os delitos individuais. No entanto, uma análise sem nexo e embasamento argumentativo, pois os crimes e penas de agentes individuais permaneceram, só que agora ao lado de crimes e penas das pessoas jurídicas.

Pelo exposto, verifica-se a viabilidade na aplicação de sançóes a todas as pessoas, sejam físicas ou jurídicas, como forma de coibir o avanço da degradação ambiental.

\section{Conclusões}

Assim sendo, constatou-se que apesar do STF recentemente ter decidido pela responsabilização da pessoa jurídica por delitos ambientais difere do STJ quanto à dissociação da culpabilidade da pessoa física e do ente moral.

Quando o administrador agir em nome da empresa e causar um delito ecológico, ambos devem ser responsabilizados conjuntamente, o primeiro devido a sua conduta dolosa ou culposa e a segunda responde objetivamente por ter sido criada (risco social) para facilitar a realização do evento criminoso. Se por outro lado, o dirigente realiza uma ação ou omissão delituosa ambiental e não utiliza a pessoa jurídica, fica evidente que não poderá ser responsabilizada pelo crime ambiental.

A pessoa jurídica somente poderá ser imputada criminalmente se a pessoa física também for responsabilizada. Caso contrário, a separação da responsabilização dos dirigentes e da pessoa jurídica pode trazer grandes injustiças no que se refere à utilização da corporação por funcionários que querem prejudicar a própria empresa, ou utilizá-la para acobertar as suas condutas delituosas e transferir a responsabilidade exclusivamente para os entes coletivos. Torna-se, portanto, inconcebível a penalização isolada do ente coletivo.

\section{Referências}

BACIGALUPO, Silvina. Responsabilidad Penal de las Personas Jurídicas. Buenos Aires: Editorial Hammurabi SRL, 2001. 
BAIGÚN, David. La Responsabilidad Penal de las Personas Jurídicas (Ensayo de un Nuevo Modelo Teórico). Buenos Aires: Ediciones Depalma, 2000.

BECCARIA, Cesare Bonesana (tradução: Lúcia Guidicini e Alessandro Berti Contenssa). Dos Delitos e das Penas. São Paulo: Martins Fontes, 1999.

BRASIL. LEI DE PROTEÇÃO AMBIENTAL DA REPÚBLICA FEDERATIVA DO BRASIL - número 9.605/98. Boletim Oficial de 12 de fevereiro de 1998. Disponível em <http://www.planalto.gov.br/ccivil_03/Leis/L9605.htm>. Acesso em: $15 \mathrm{de}$ fev. 2015 .

. SUPERIOR TRIBUNAL DE JUSTIÇA - STJ. Disponível em <http://www.stj. gov.br>. Acesso em: 19 de abr. 2015.

. SUPREMO TRIBUNAL FEDERAL - STF. Disponível em <http://www.stf. gov.br>. Acesso em: 19 de abr. 2015.

BREDA, Juliano. A Inconstitucionalidade das Sançôes Penais da Pessoa Jurídica em Face dos Princípios da Legalidade e da Individualização da Pena. In: PRADO, Luiz Regis. DOTTI, René Ariel (coordenadores). Responsabilidade Penal da Pessoa Jurídica: Em Defesa do Princípio da Imputação Penal Subjetiva. São Paulo: Editora RT, 2010 .

CANOTILHO, José Joaquim Gomes. Direito Constitucional e Teoria da Constituição. Coimbra: Livraria Almeidina, 2000.

CÓDIGO PENAL - CÓDIGO DE PROCESSO PENAL - CONSTITUIÇÃO FEDERAL DO BRASIL. São Paulo: Saraiva, 2015.

COSTA, Helena Regina Lobo da. Proteção Penal Ambiental: Viabilidade - Efetividade - Tutela por Outros Ramos do Direito. São Paulo: Saraiva, 2010.

FIORILlO, Celso Antonio Pacheco. Curso de Direito Ambiental Brasileiro. São Paulo: Saraiva, 2002.

GOLDBLATT, David (tradução: Ana Maria André). Teoria Social e Ambiente. Lisboa: Instituto Piaget, 1996.

IENNACO, Rodrigo. Responsabilidade Penal da Pessoa Jurídica. Curitiba: Juruá, 2010 .

JAKOBS, Günther (tradução: Carlos J. Suárez González). ¿Punibilidad de las Personas Jurídicas? In: GARCÍA CAVERO, Percy (coordenador). La Responsabilidad Penal de las Personas Jurídicas, Órganos y Representantes. Mendoza: Ediciones Jurídicas Cuyo, 2004.

JESUS, Damásio Evangelista de. Imputaçáo Objetiva. São Paulo: Saraiva, 2000. 
LÓPEZ MESA, Marcelo J. ; CESANO, José Daniel. El Abuso de La Responsabilidad Jurídica de las Sociedades Comerciales: Contribuciones a su Estudio desde las Ópticas Mercantil y Penal. Buenos Aires: Ediciones Depalma, 2000.

MACHADO, Paulo Affonso Leme. Direito Ambiental Brasileiro. São Paulo: Malheiros, 1998.

MORAES, Luís Carlos Silva de. Curso de Direito Ambiental. São Paulo: Atlas, 2002.

MUNONOZ-CONDE, Francisco. Los Delitos Patrimoniales y Económicos. Disponivel em<http://www.cienciaspenales.net/descargas/idp_docs/doctrinas/los\%20delitos\%20patrimoniales\%20y\%20economicos\%20munoz\%20conde.pdfs. Acesso em: 20 de abr. 2015.

ROCHA, Fernando A. N. Galvão da. Responsabilidade Penal da Pessoa Jurídica. Belo Horizonte: Del Rey, 2003.

ROXIN, Claus (tradução: Luís Greco). Tem Futuro o Direito Penal? In: Estudos de Direito Penal. Rio de Janeiro: Renovar, 2008.

SOARES, Jardel de Freitas. La Criminalidad Ambiental de las Empresas en el Mercosur. Cajazeiras: Real, 2013.

SEELMANN, Kurt (tradução: Percy García Cavero). Punibilidad de la Empresa: Causas, Paradojas y Consecuencias. In: GARCÍA CAVERO, Percy (coordenador). La Responsabilidad Penal de las Personas Jurídicas, Órganos y Representantes. Mendoza: Ediciones Jurídicas Cuyo, 2004.

SHECAIRA, Sérgio Salomão. Responsabilidade Penal da Pessoa Jurídica. São Paulo: Editora RT, 1998.

ZAFFARONI, Eugenio Raúl. Parecer a Nilo Batista Sobre a Responsabilidade Penal da Pessoa Jurídica. In: PRADO, Luiz Regis. DOTTI, René Ariel (coordenadores). Responsabilidade Penal da Pessoa Jurídica: Em Defesa do Princípio da Imputaçáo Penal Subjetiva. São Paulo: Editora RT, 2010. 